\title{
HUMAN RESOURCE MANAGEMENT - PRESENT AND FUTURE PROSPECTS
}

\section{E.A.Tarța}

\section{Eugenia-Anişoara Tarţa}

Law and Economics Faculty, Social Sciences Department

Agora University of Oradea, Oradea, Romania

*Correspondence: Eugenia-Anişoara Tarţa, Agora University of Oradea,

8 Piaţa Tineretului St., Oradea, Romania

E-mail: jenitarta@yahoo.com

\begin{abstract}
Human resource management consists of all the activities geared towards ensuring, developing, motivating and keeping human resources in an organization in order to achieve its objectives as efficiently as possible and meet the needs of the employees.
\end{abstract}

\section{Introduction}

The human resources of a company play a major part in its development. The concept of human resources is not new. Peter Drucker in his book "The Practice of Management" underpinned the three functions of management: the achievement of economic performance, the leading of managers and the management of workers and labor. Human resources can be defined as one of the most important investments an organization can make whose results become more evident over time. It can be said that human resources are the organization itself.

\section{HUMAN RESOURCES -THE STRATEGIC RESOURCE OF AN ORGANIZATION}

The human resources of a company play a major part in its development. The concept of human resources is not new. Peter Drucker in his book "The Practice of Management" underpinned the three functions of management: the achievement of economic performance, the leading of managers and the management of workers and labor. Human resources can be defined as one of the most important investments an organization can make whose results become more evident over time. It can be said that human resources are the organization itself. Given the fact that modern society presents itself as a network of organizations that appear, develop or disappear, people are a shared resource and also a key resource, as well as a vital resource to ensure the survival, development and competitive success of all organizations. Without the effective presence of men who know what, when and how to do things, it is simply impossible for organizations to achieve their goals.(http://hosted.regionalnet.org/asper/managementul_resurselor_umane.html)

Thus, organizations exist because people have different physical and intellectual capabilities as well as the ability to develop the organization. Therefore, organizations involve people and alsodepend on human effort.

Organizations spend significant amounts of money on their employees, and due to the costs involved, staff remuneration as well as staff hiring, retention and development, are some of the most obvious investments in human resources.In conclusion, investing in people has turned out to be the surest way to ensure the survival of an organization as well as its competitiveness and future.

The view that the human factor involves some costs and capital expenditures is opposed to the need highlighted by many human resource professionals to treat the staff as a 
capital investment for further development of any organization. We can therefore say that the human resource is the first strategic resource of any organization. Their strategic importance is highlighted by the fact that they are an essential variable in the success or failure of any organization.

Human resources are unique in terms of their potential for growth and development as well as their ability to know and overcome their own limits, meet new challenges,present and future demands.

Human resources are the only endless, original and valuable source of creativity, solutions and new ideas. People have the potential to create material and spiritual goods of a higher value that would satisfy new requirements or respond better to the old requirements. They are the ones who design and make goods and services, perform quality control, provide resources, make decisions and above all establish or develop objectives and strategies. People are considered to be the assets of any organization because their potential, experience, passion, endeavors and development actively contribute to the improvement of the organization's efficiency and effectiveness. This is why organizations need to hire people, gain their services, develop their skills, motivate them to work and make sure that the staff will continue to maintain their commitment to the organization.(Marius Dan Dalotă, 2000: 7)

Convinced that human resources are the main strategic resource of any organization, any leader must give utmost importance to such activities as: attracting and using the human resources, ensuring compatibility between job requirements and competence of staff, training and developing the human resources, managing the careers of the staff, assessing professional performance, motivating staff and last but not least, establishing a system that would bring satisfaction and the opportunity to reconcile personal goals with the goals of the organization.

Human resources are strongly influenced by the time factor which is essential if we are tochange mentalities, customs, behavior, etc. Therefore, the importance of human resources and their management has become greater with time due to the increasing need for organizations to be more dynamic and competitive. From a temporary point of view, the role of human resources and their management is constantly increasing because of the great opportunity to exploit human potential since people are increasingly concerned about improving the quality of their personal and professional lives so that they would better reflect their aspirations.(Emilia Novac, Denisa Pop-Abrudan, 2006: 11)

Therefore we can say that human resources represent the creative, active and coordinating component of all activities taking place within organizations. In conclusion, from the point of view of human resources management, people are not recruited and selected only to fill certain vacancies but for their important role within the organization. Particularly in an ever-changingand tumultuous environment where a number of variables are beyond control and where the difficulties that organizations face are more and more imputed to human resources and their management.

\section{THEORIES ON HUMAN RESOURCES MANAGEMENT}

Human resources management has become distinctive and independent, has limited its object of study, therefore becoming specialized and well-established within the context of general management; however, the human resources management emerges from the general management.

Human resource management is a relatively recent term for what was originally called "personnel handling", "management of personnel activity" etc. In the traditional theory of the 
enterprise, employees were assessed by the way they carried out certain predetermined operations in a "disciplined" manner or handle machines and technological devices.

Thus the concept of "labor force" and "manpower" emerged. What mattered was their ability to put into practice decisions of managers and abide by regulations. The concept of "labor force" designated the totality of physical and intellectual skills that man uses in the process of acquiring goods and services. In totalitarian regimes, there was a distinction between "productive work" as creator of material goods on the one hand, and "non-productive work" as well as" unproductive personnel "on the other hand, the latter being associated with those who carried out intellectual activities. Any action to improve labor force was aimed at improving people's ability to work more and better. The concept of labor force used always in the singular designated a whole, a crowd of people. Thus, the individual with a distinctive personality, with specific needs, behavior, and vision were not included in the objectives of the leaders.

Human resource management involves continuous improvement of employee activity in order to achieve the mission and objectives of an organization.

The exercise of such management requires that each manager be a model of behavioral attitude. Thus, the manager must take responsibility for the process, be involved in every action, personally discuss with employees the progress they made and reward good results. The managermust treat each employee as an individual with distinct characteristics. The successful application of human resource management involves a system of performance assessment, of incentives and rewards for good results. The following table (Table nr.1.1) illustrates the differences between the traditional theory of enterprise and human resource management and their attitudes towards the staff.

Table nr.1.1 Differences between traditional theory ofenterprise and human resource management.

\begin{tabular}{|c|c|c|}
\hline Description elements & $\begin{array}{l}\text { The traditional theory of } \\
\text { enterprise }\end{array}$ & $\begin{array}{l}\text { Human Resource } \\
\text { Management }\end{array}$ \\
\hline Concepts used & Labor force, manpower & Human resources \\
\hline $\begin{array}{c}\text { Types of discriminating } \\
\text { character }\end{array}$ & $\begin{array}{c}\text { "Productive labor" } \\
\text { "Creator of material goods" }\end{array}$ & \\
\hline $\begin{array}{l}\text { Manager's ways of treating } \\
\text { the staff }\end{array}$ & $\begin{array}{l}\text { As a whole, as a crowd of } \\
\text { people able to work }\end{array}$ & $\begin{array}{c}\text { As individuals, with } \\
\text { distinctive personalities, } \\
\text { needs, behavior and vision }\end{array}$ \\
\hline The basis for pay & $\begin{array}{l}\text { According to the work } \\
\text { carried out }\end{array}$ & $\begin{array}{l}\text { According the results } \\
\text { obtained }\end{array}$ \\
\hline Assessment of performance & Insignificant, formal & Essential \\
\hline $\begin{array}{c}\text { Stimulating the actions of } \\
\text { employees }\end{array}$ & $\begin{array}{l}\text { Any action on the part of the } \\
\text { employee was thought to } \\
\text { undermine the authority of } \\
\text { the boss }\end{array}$ & $\begin{array}{l}\text { Actions by employees were } \\
\text { supported and encouraged } \\
\text { through payment systems }\end{array}$ \\
\hline
\end{tabular}

This system seeks a permanent collaboration of the employees in order to improve the quality of the products and services provided by the organization as well as its development and objectives and to ensure long-term viability and profitability in line with requirements.

In literature there is a relatively great number of definitions of human resource management. Currently, theoretical and practical meanings of human resource management were amplified 
to such an extent that any attempt at translation or definition would be difficult to achieve.

Trying to overcome existing difficulties, specialists have defined human resource management as follows:

- The function that enables the most efficient use of people in order to achieve individual and organizational objectives;

- The function that enables organizations to fulfil its objectives by achieving and maintaining an effective workforce;

- A strategic approach to acquiring, motivating and developing the key resources of an organization;

-It establishes aims in relation to men, achieving and controlling them in a logic of the system;

- It involves all management-related decisions and practices that directly affect humans or human resources working in the organization;

- It involves multiple decisions that affect the relationship between employers and employees and other stakeholders;

- It involves multiple decisions concerning the employment relationship which influences the effectiveness of the employees and of the organization;

- All the activities geared at the human factor seeking to acquire, make optimal use of, maintain and develop human resources;

- All activities meant to ensure the optimal use of human resources for the benefitof the organization, the employees, and the community as a whole;

- All decisions affecting the relationships between the main social partners (employers and employees) meant to ensure increased productivity and efficiency of economic activity;

- A system of interdisciplinary measures concerning the recruitment, selection, classification, use of staff in the context of ergonomic labor, material and moral stimulation, until cessation of employment;

These are just some of the definitions of human resource management, and although most of the definitions presented can be considered fair, some of these cannot be considered as being comprehensive enough if we consider the extremely complex nature of human resource management. The definitions referred to are not contradictory, but complement each other, each definition giving an insight into the concept of human resource management. Therefore, we can say that at present there is no universally accepted definition on human resource management. It may be noted that the definitions referred to do not contain conflicting elements but elements that complement each other, each helping to enhance the concept of human resource management.

Human resource management contributes to increased economic and social efficiency of a company, by taking to a higher level the business activities of a company in the context of the national market and economy, based on economic criteria, fact which results in absolute and relative savings in the areas of manpower and materialized labor which benefit both the economic unit and the systemsin which it is integrated.

The contribution of human resource management is not limited to the economic side; social efficiency isparticularly important, which involves aspect that cannot be measured directly, but which have multiple consequences for all those involved in the activities of the company and, above all, for the human factor. We highlight some elements of social efficiency: the quality of internal climate; the fluidity of hierarchical relations which depends on the level of communication within the organization; the intensity and content of personnel motivation; intensity of the feeling of belonging to the organization etc.

Effective management of human resources is essential for a company's success. If human resources are neglected or poorly managed the company ceases to be prosperous and may even regress. 
The efficiency ofhuman resource management within a company can be approached from two points of view:

- From a limited point of view, it depends on the direct efforts of the company to make the management system work and to improve it as well as on its direct effects. By comparing the two terms we can assess the effectiveness of the human resource management based on its direct consequences;

- The second point of view looks atthe efficiency of the human resource management in a broader sense as determined by the efforts and results arising from the activity of the organization as a whole. The premise underlying this approach lies in treating the management as an essential means- if not the most important- for the success and profitability of the company.

Whichever approach you may be using, the effective human resource management takes two forms in terms of the means of expression and measurement:

- Quantifiable efficiency concerns quantitative measurement and expression in the form of value, usually, of the inputs and outputs of a company;

- Unquantifiable efficiency refers to those functional and qualitativeaspects relating in particular to the human factor and behavior and interactions that can be measured fully or very roughly and which can negatively impact the economic performance of the company.

Although HR has continuously enriched its contents and broadened its scope; the increasinginternational competition and globalization reinforce the importance of human resource management, and make us take consider more thoroughly its international dimension.

\section{STAGES OF DEVELOPMENT OF HUMAN RESOURCE MANAGEMENT}

Over time, the management of human resources has had different periods or stages of development which have generated some different opinions, arguments and polemics.

For full understanding of the current concept of human resource management, it is necessary to understand its historical evolution. One type of periodization presented in literature and accepted by many experts in human resources management comprises the following stages:

- The empirical stage

- The welfare or prosperity stage

-Staff handling

- Personnel management-the development phase

- Staff management-the mature phase 
I - Human resources management - first phase

- Human resources management - the second phase.

The empirical stage - has its beginnings in ancient times and lasted until the late 19th century. It is the stage where the owner, as sole holder of the capital, had a dual role and status and as a sole owner he had to solve all tasks including the organization of work. He was led by intuition, common sense, tradition and experience, and staff-related activities particularly targetedthe technical and organizational side and occasionally managerial aspects as success was considered the exclusive result of certain personal qualities.

The welfare and prosperity stage- its founder is Frederic W. Taylor. This stage is characterized by a process of halving, as the technical and organizational side of the business is left to officials of the capital, which usually have no capital, while the owner remains the only direct subject of social-economic management. It's the boom period of capitalism, where owners are increasingly concerned with improving working conditions and providing facilities for employees (canteen, medical programs).

Staff handling- is the stage of development of the staff position, which, in time, may be located in between the two world wars and the new demands in human resources from the increased size and complexity of the activities of organizations. The development of trade unions and labor legislation of the 1930s has led to an increasing involvement of organizations in collective bargaining and resolved claims of employees. The school of human resources, represented by Mayo stressed the importance of people's social needs and psychological variables. Concerns regarding the study of environmental factors, the organization of work and rest regime, and the implementation of a participatory leadership style increased.Staff compartments were created in companies which contributed to the development of the staff position.

Staff management - development phase - is the stage belonging to World War II and the 1950s, when postwar reconstruction, the rapid expansion of organizations, the technological change and internationalization of the economycreated favorable conditions for the development of the HR position. There was a labor shortage. All these issues have led to a certain priority in the areas of staff recruitment, remuneration, and restructuring of services provided by the staff, marking the beginning of modern staff management.

Staff Management - mature phase - this phase is specific to the years 1960's-1970's and is characterized by a comprehensive approach to human resources issues through greater involvement of staff managers in human resource strategy and strategic problems of an organization. Human resource planning methods developed whileselection, training and assessment methods and techniques undergo a continuous process of improvement.

Human resources management - first phase - is characteristic of the 1980s entrepreneurial period when in American universities the concept of human resource management appears while the staff position is given the same status as the other positions of the organization. The concerns of this period are increasingly oriented towards determining the human dimension of organizational changes and the integration of human resource strategies into the overall strategy of the organization. 
It is the period when due to many influences and challenges, including the Japanese phenomenon, the concept of human resource management emerges and the staff positions is given the same status as the other positions of the organization. There is a new restructuring of the staff position with new activities such as planning and career development, staff motivation, reward based on performance, safety and health of employees being included in this position.

Human resources management - the second stage - was triggered in the early 1990s and appears as a reaction to the unsupported features of organizational culture: individualism and greed which highlighted the need to promote the benefits of teamwork and organizational climate. We can note the importance attached to issues of motivation and communication, as well as to relatively new concepts, for example, reward management, culture management, etc. This continuous development of human resource management led to its gradual transformation from a strictly defined and narrow area to a strategic position. Therefore, at this stage the particularly important contribution of staff activities and human resource strategies and policies to the success of the organization is revealed as well as the importance of training specialists in the field.

\section{FACTORS AFFECTING THE HUMAN RESOURCE MANAGEMENT}

The factors which influence the human resource management are: the motivational structure of employees and collaborators; their values and oscillation; internationalization; the political and social context; the labor market; the level of information; the organization; the market dynamics; developments in technology.

The preoccupation for human resource management started primarily with themotivational structure of current and future collaborators, structure resulting in:

- The accuracy of tasks;

- The attitude towards work: as a dominant mechanism of individual fulfillment or not.

There can be serious consequences on human resource management caused by changes in the labor market, namely:

- Structural displacement regarding supply;

- Changes in the demand.

The labor market is an important factor affecting the work of the staff of an organization. If the organization fails to realize in time the structural changes in the labor market and therefore to react with appropriate measures difficulties cannot be presented. Therefore it is not surprising that the organization firstly investigates the fluctuations in the labor market and is interested in long-term reports and projects.

Market, technology and organizationdynamics substantially influences the human resource management. Regardless of changes in quality, only quantitative market changes can lead to increased market dynamics. This has a direct influence on an organization's human resource management. 
Changes in markets inevitably lead to a new demand of staff, both qualitative and quantitative, and with this to a change of the methods to get more staff as well as increased expectations towards the evolution of staff.

Increased international interdependence and globalization of markets has led to an internationalization of the activity of organizations. As a result of this internationalization organizations must face a number of problems such as:

- Integrating commitments to foreign countries;

- management of the organization;

- control of daughter companies abroad;

- International fiscal policy.

Human resource management has to solve a lot of operative problems such as: selection, training, guidance and reintegration of foreign labor. The human resource management is further faced with problems of different cultural systems. These particular elements will have great influence even in the future over the international human resource management.

Another influence on human resource management is that of values and their oscillations. Values are preferential individual cognitive structures that act as elements in a decision, finally determining the employee's behavior.

Although values refer exclusively to an individual, organizations are interested in them, because they may turn out authentic, change or cause conflicts within a group. Precisely because of this, an organization must pay attention from the beginning to all signals indicating values and their change. Therefore, we are increasingly witnessing a change in the attitude towards work, free time and pay.

The causes of these changes are very controversial. On the one hand, they say it's the education and the media; on the other hand it's the search for and discovery of other forms of self-fulfillment such as the use of leisure time by the employee.

The main consequence, with an impact on human resource management, is that more and more partners require more interesting and variedactivities, which will influence the decisions. Because of this, human resource management must have a value-oriented staff policy, and this policy must begin with a thorough staff selection. 


\section{BIBLIOGRAFIE}

Armstrong, Michael Managementul resurselor umane, EditionsCodecs, Bucureşti, 2003

Androniceanu, A., Noutăţi in managementul public, Editura Universitară, Bucureşti, 2005

Androniceanu, A., Sisteme administrative in statele din Uniunea Europeana - studii comparative, Editura Universitară, Bucureşti, 2008

Bali, Rajeev, K., ClinicalKnowledge Management : OpportunitiesandChallenges, Idea Group Publishing, Hershey, 2005

Burduş, E., Tratat de management, Editura Economică, Bucureşti, 2006

Handzic, M., Knowledge Management : Throughthe Technology Glass, World ScientificPublishing Company, River Edge, 2005

2003

Hipp, K., Professional learningcommunities: Initiationtoimplementation, Scarecrow Press, Lanham,

Ionescu, Gh.. Cultura organizaţională şi managementul tranziţiei, Editura Economică, Bucureşti, 2001

Metcalfe, Amy S., Knowledge Management andHigherEducation : A Criticai Analysis, Information SciencePublishing, Hershey, 2005

Năstase, M., Lideri, leadership şi organizaţia bazată pe cunoştințe, Editura ASE, Bucureşti, 2007

Năstase, M., Cultura organizaţională şi cultura managerială, Editura ASE, Bucureşti, 2004

Laroche, Hervé Management. Aspectshumains et organisationnels, PUF Fondamental,

Nicolescu, O., Nicolescu, L., Economia, firma şi managementul bazate pe cunoştinţe, Ed. Economică,

Petroni, G.; Cloete, F, New technologies in public administration, IOS Press, Oxford, 2005

Profiroiu, M., Politici publice, Editura Economică, Bucureşti, 2006 